\title{
Dermoid of the floor of the mouth
}

\author{
Frank J. Welte • Ajay Malhotra
}

Received: 12 November 2009 /Revised: 29 November 2009/Accepted: 31 December 2009/Published online: 22 January 2010

(C) Springer-Verlag 2010

A 4-year-old girl presented with a floor-of-mouth mass. MRI showed a midline, $\mathrm{T} 2$ hyperintense, well-circumscribed mass superior to the mylohyoid muscle and splaying the geniohyoid muscles (Figs. 1 and 2). Several nonenhancing ovoid nodules with restricted diffusion were present in the anterior section of the lesion. Differential diagnoses included dermoid or epidermoid cyst, plunging ranula, and lymphatic malformation. Post-resection pathology demonstrated findings indicative of a dermoid.

Dermoid cysts can contain fat, hair follicles, or other skin appendages and are lined by a keratinizing squamous epithelium. In contrast, epidermoid cysts are lined by a

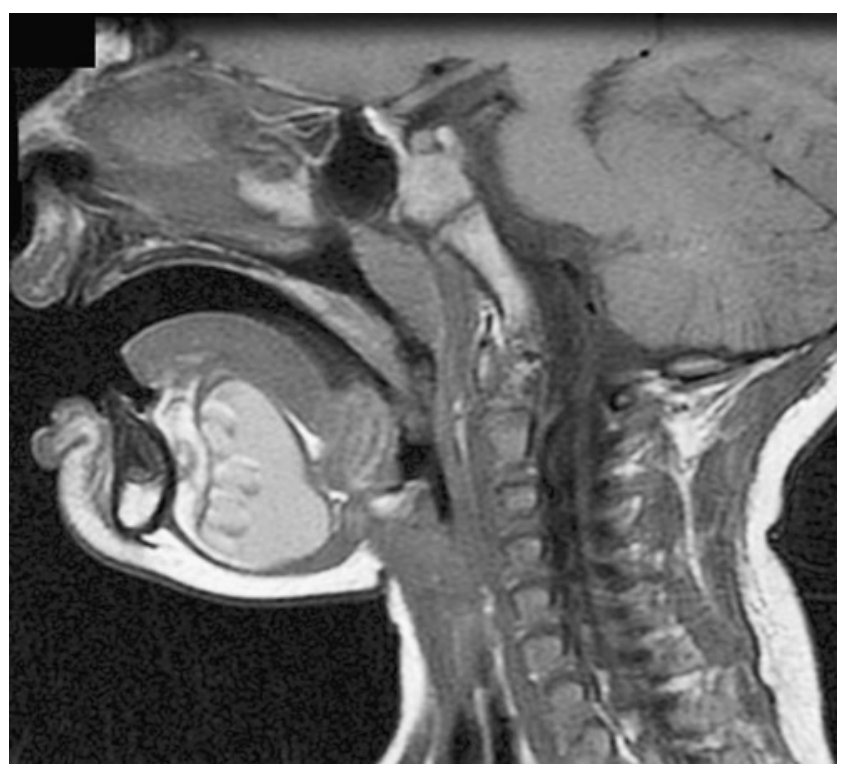

Fig. 1 T1-W MRI

F. J. Welte $(\triangle) \cdot$ A. Malhotra

Diagnostic Radiology, Division of Neuroradiology,

Yale New Haven Hospital,

333 Cedar St. (CB-30),

New Haven, CT 06510, USA

e-mail: fjwelte@gmail.com

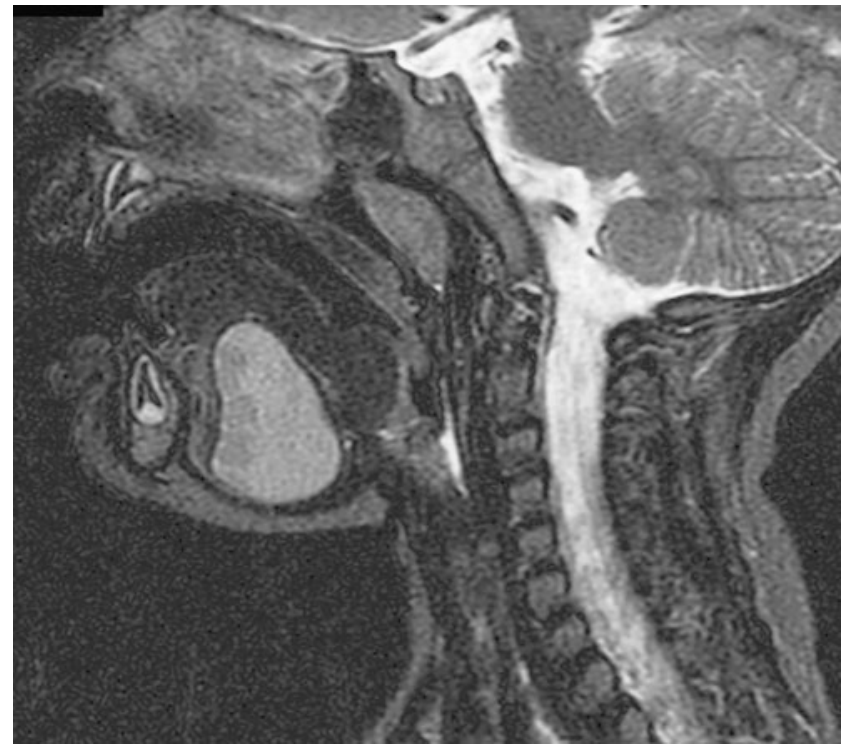

Fig. 2 T2-W MRI

simple squamous epithelium and surrounding fibrous connective tissue. Dermoid and epidermoid cysts arise from the first and second branchial arches after sequestration of surface ectodermal tissue. The rare teratoid cyst contains elements of all three germ cell layers [1,2]. The location of these lesions with respect to the mylohyoid muscle is important for determining the most appropriate surgical approach. These benign lesions are equally common in boys and girls and typically present in infancy as painless masses. Surgical resection is curative.

\section{References}

1. Koeller KK, Alamo L, Adair CF et al (1999) Congenital cystic masses of the neck: radiologic-pathologic correlation. Radiographics 19:121-146, quiz 152-153

2. Pryor SG, Lewis JE, Weaver AL et al (2005) Pediatric dermoid cysts of the head and neck. Otolaryngol Head Neck Surg 132:938-942 